\title{
Contribution of proteases and cellulases produced by solid-state fermentation to the improvement of corn ethanol production
}

\author{
Anaïs Guillaume ${ }^{1 *} \mathbb{D}$, Aurore Thorigné ${ }^{1}$, Yoann Carré ${ }^{1}$, Joëlle Vinh ${ }^{2}$ and Loïc Levavasseur ${ }^{1}$
}

\begin{abstract}
By cultivating a strain of Aspergillus tubingensis on agro-industrial by-products using solid-state fermentation technology, a biocatalyst containing more than 130 different enzymes was obtained. The enzymatic complex was composed mainly of hydrolases, among which a protease, an aspergillopepsin, accounted for more than half of the total proteins. Cell-wall-degrading enzymes such as pectinases, cellulases and hemicellulases were also highly represented. Adding the biocatalyst to corn mash at $1 \mathrm{~kg} / T$ corn allowed to significantly improve ethanol production performances. The final ethanol concentration was increased by $6.8 \%$ and the kinetics was accelerated by $14 \mathrm{~h}$. The aim of this study was to identify the enzymes implicated in the effect on corn ethanol production. By fractionating the biocatalyst, the particular effect of the major enzymes was investigated. Experiments revealed that, together, the protease and two cellulolytic enzymes (an endoglucanase and a $\beta$-glucosidase) were responsible for $80 \%$ of the overall effect of the biocatalyst. Nevertheless, the crude extract of the biocatalyst showed greater impact than the combination of up to seven purified enzymes, demonstrating the complementary enzymatic complex obtained by solid-state fermentation. This technology could, therefore, be a relevant natural alternative to the use of GMO-derived enzymes in the ethanol industry.
\end{abstract}

Keywords: Solid-state fermentation, Enzymes, Protease, Cellulases, Bioethanol, Corn, Purification, Characterization

\section{Introduction}

The use of solid-state fermentation technology to produce industrial enzymes is common in eastern countries such as India, China or Japan, and has been of growing interest for numerous applications worldwide over the past few decades (Bhargav et al. 2008; Brahmachari 2017; Subramaniyam and Vimala 2012). This technology can be used with a wide range of microorganisms, including fungi, yeasts and bacteria. It is particularly well suited to fungal species such as of Aspergillus and Trichoderma, to produce hydrolytic enzymes like amylases and cellulases, among others (Carboué et al. 2016; Singh et al. 2008; Pandey et al. 1999). Solid-state fermentation (SSF) has several advantages over submerged fermentation. From a

\footnotetext{
*Correspondence: aguillaume@soufflet.com

${ }^{1}$ Centre de Recherche et Innovation Soufflet, Ets J. Soufflet, Quai Sarrail,

10402 Nogent-sur-Seine cedex, France

Full list of author information is available at the end of the article
}

biotechnological point of view, it shows higher volumetric productivity, higher product stability, and lower catabolite repression (Hölker et al. 2004; Ashokkumar et al. 2001; Diaz-Godinez et al. 2001). Comparisons of metabolites resulting from solid-state or submerged fermentation attest that fungal metabolism is activated differently depending on the technology: Oda et al. (2006), for example, showed that secreted enzymatic complexes were of different composition according to whether the microorganism was cultivated under solid-state or submerged fermentation. With regards to environmental impact and economics, SSF is less water and time consuming, and it generates less waste. It is a relatively low-cost technology and it uses agro-industrial by-products or waste as substrate (Carboué et al. 2016; Panda et al. 2016).

The addition of enzymes is essential in the biochemical conversion of starchy and lignocellulosic biomass into fuel ethanol. Although starch-to-ethanol processes are already efficient, numerous recent works have evidenced 
that the use of accessory enzymes, besides amylases, could increase significantly ethanol yields and process efficiency in the corn ethanol industry (Klosowski et al. 2010; Mikulski et al. 2015). Especially, protease was shown to increase fermentation rate (Vidal et al. 2009) and ethanol yield by liberating free amino acids for the yeast (Perez-Carrillo et al. 2012; McAloon and Johnston 2014). Protease and possibly phytase have also shown positive impact on oil recovery in the corn dry-grind process (Luangthongkam et al. 2015). Cellulases and xylanases may also help in releasing starch bound to the corn fiber, and induce cost and energy savings by decreasing viscosity and reducing water binding to grains, thus facilitating centrifugation and drying steps (Harris et al. 2014).

A few research studies deal with producing several different enzymes with one microorganism by solid-state fermentation (Chutmanop et al. 2008; Mukhtar and Ikram-Ul-Haq 2009). The potential use of enzymatic complexes produced by SSF to lower the cost of enzymes in the ethanol process while valorizing by-products or residues such as distillers grains has also been reported (Hoskins and Lyons 2009; de Castro et al. 2011; Singhania et al. 2015). However, little literature relates to the understanding of the applicative effect measured using enzymatic complexes obtained by SSF.

Previous works of strain and substrate screening and solid-state fermentation process optimization were carried out as part of the Osiris Program (data not published). It resulted in the development of a biocatalyst having a significant positive effect on corn ethanol fermentation process, for which a patent was filed (Guillaume et al. 2016). The aim of this work was to better understand the effect of this enzymatic product obtained by SSF on the production of ethanol from corn. Extensive characterization and fractionation of the biocatalyst were carried out to specify which enzymes were responsible for the overall effect measured.

\section{Materials and methods Biocatalyst production}

The conditions of strain cultivation (temperature, humidity, air flow, stirring, kinetics) were previously studied and optimized to maximize enzyme concentration in the final product (data not published).

\section{Microorganism}

The microorganism used in this study to produce enzymes was the strain of Aspergillus tubingensis $\mathrm{O} 27$ from Soufflet's collection of microorganisms. The strain was cultivated in potato dextrose agar (PDA) at $30{ }^{\circ} \mathrm{C}$ for 13 days prior to use, to obtain maximal viable spores.

\section{Solid-state fermentation}

A previous screening of several agricultural coproducts allowed to select a mix of rapeseed meal and wheat bran as a substrate, based on its textural, nutritional and enzyme inductor properties (data not published).

Fermentation medium contained $70 \%(\mathrm{w} / \mathrm{w})$ rapeseed meal and $30 \%(\mathrm{w} / \mathrm{w})$ wheat bran. The humidity of medium was adjusted with water to reach a final moisture level of $55 \%$. Solid-state fermentation was carried out in a rotary-type automatic Koji-making equipment (Fujiwara Techno-Art Co., Ltd.) with $10 \mathrm{~kg}$ of initial dry matter of sterile fermentation medium. The medium was inoculated with $10^{7}$ spores/g of initial dry matter and incubated at $33{ }^{\circ} \mathrm{C}$ for $51 \mathrm{~h}$ with a continuous ventilation of $35 \mathrm{~Hz}$ and discontinuous stirring. Water was added during culture to maintain the moisture level at $55 \% \pm 2 \%$. Solid-state fermentation was stopped by adding propionic acid.

\section{Biocatalyst}

At the end of SSF, the fermented medium was dried at $45{ }^{\circ} \mathrm{C}$ during $18 \mathrm{~h}$ to obtain a dry matter content of $90 \%$. It was then ground with a Retsch Ultra Centrifugal Mill ZM300 using a $0.85-\mathrm{mm}$ grid. The dry product, thus, obtained was called biocatalyst. It was stored at $-20{ }^{\circ} \mathrm{C}$. These conditions of post-treatment of the fermented medium were determined to preserve the product efficiency and enzymatic activities (data not shown).

\section{Crude extract}

For utilization in corn ethanol fermentation, a crude extract of the biocatalyst was prepared by adding water to the dry product $(1 / 10 \mathrm{w} / \mathrm{v})$, allowing for the soluble compounds to extract to the aqueous phase for 10-15 min at room temperature with moderate stirring (optimal time for maximum enzymatic activities in the extract). For proteomic analysis, the crude extract was centrifuged for $10 \mathrm{~min}$ at $3000 \mathrm{rpm}$ at $20{ }^{\circ} \mathrm{C}$ to eliminate insoluble particles. The resulting extract contained $15 \mathrm{~g} / \mathrm{L}$ of proteins.

\section{Characterization of proteins and enzymes Quantification of proteins}

Protein concentrations were determined by DC protein Assay kit from Bio-Rad (Catalog Number 500-0116), according to the instruction manual. 


\section{Enzymatic assays}

- $\beta$-Glucosidase (GLP) and cellobiohydrolase (cellp) activities were estimated using, respectively, $\mathrm{p}$-nitrophenyl $\beta$-D-glucopyranoside and p-nitrophenyl $\beta$-D-cellobioside (Sigma) as substrates. $\beta$-Glucosidase activity was inhibited by D- $(+)$-gluconic acid $\delta$-lactone according to the procedure described by Gao et al. (2011). The assay mixture consisted of volume of substrate $(0.58 \mathrm{mg} / \mathrm{mL}$ and $1.00 \mathrm{mg} / \mathrm{mL}$, respectively) and half volume of enzymatic solution suitably diluted with acetate buffer $0.05 \mathrm{M} \mathrm{pH} 4.5$. It was incubated at $30{ }^{\circ} \mathrm{C}$ and $40{ }^{\circ} \mathrm{C}$ (respectively) for $15 \mathrm{~min}$. The reaction was stopped with $160 \mu \mathrm{L}$ of $1 \mathrm{M}$ glycine pH 9.0 for GLP and 7.5\% $(\mathrm{w} / \mathrm{v})$ sodium carbonate for cell-p. The $p$-nitrophenol liberated was measured at $405 \mathrm{~nm}$ and $420 \mathrm{~nm}$, respectively. One unit of enzyme activity was defined as the amount of enzyme required to liberate $1 \mu \mathrm{mol}$ of $p$-nitrophenol (pNP) per minute under the standard assay conditions.

- To detect and quantify $\beta$-glucanase (AGL), xylanase (AXC) and cellulase (CMCell) activities, AzoBarley glucan, Azo-Xylan of Birchwood and AZOCM-cellulose (Megazyme) were, respectively, used as substrates. The enzymatic solutions diluted with acetate buffer at $0.1 \mathrm{M} \mathrm{pH} 4.6$ (AGL and AXC) or $0.4 \mathrm{M} \mathrm{pH} 4.7$ (CMCell) were incubated with the substrate at $30{ }^{\circ} \mathrm{C}$ or $40{ }^{\circ} \mathrm{C}$ for 10 or $20 \mathrm{~min}$. The reaction was stopped with $3.0 \%(\mathrm{w} / \mathrm{v})$ sodium acetate $\left(\mathrm{CH}_{3} \mathrm{COONa} \cdot 3 \mathrm{H}_{2} \mathrm{O}\right), 0.3 \%$ (w/v) zinc acetate and $70 \%(\mathrm{v} / \mathrm{v})$ ethanol solution $\mathrm{pH} 5.0 ; 500 \mu \mathrm{L}$ of $96 \%$ $(\mathrm{v} / \mathrm{v})$ ethanol solution and $500 \mu \mathrm{L} 4.0 \%(\mathrm{w} / \mathrm{v})$ sodium acetate $\left(\mathrm{CH}_{3} \mathrm{COONa} \cdot 3 \mathrm{H}_{2} \mathrm{O}\right), 0.4 \%(\mathrm{w} / \mathrm{v})$ zinc acetate and $80 \%(\mathrm{v} / \mathrm{v})$ ethanol solution $\mathrm{pH} 5.0$, respectively, for AGL, AXC and CMCell activities. The optical density of the supernatant was measured at $590 \mathrm{~nm}$. One unit is the amount of enzyme which, diluted at $1 \mathrm{U} / \mathrm{mL}$ and used under the conditions of the assay, results in the release of non-precipitable oligomers such as the optical density of the supernatant at $590 \mathrm{~nm}$ is $0.56 ; 0.93$ and 1.0 for AGL, AXC and CMCell activities, respectively.

- Acid protease activity (PAC) was measured using casein solution $(12 \% \mathrm{w} / \mathrm{v})$ as substrate. The enzymatic solution diluted with lactate buffer $0.06 \mathrm{M} \mathrm{pH}$ 3.0 was incubated with the substrate at $40{ }^{\circ} \mathrm{C}$ for $2 \mathrm{~h}$. The reaction was stopped with $10.0 \% \mathrm{w} / \mathrm{v}$ trichloroacetic acid. The optical density of the supernatant was measured at $275 \mathrm{~nm}$. One unit is the amount of enzyme which, used under the conditions of the assay, results in the release of soluble peptides such as the optical density of the supernatant is equal to a tyrosine solution at $120 \mu \mathrm{g} / \mathrm{mL}$.

- Polygalacturonase activity (PG) was determined by using the two cyanoacetamide method described by Gross (1982).

\section{SDS-PAGE}

SDS-PAGE was performed according to the protocol described by Laemmli (1970).

\section{Identifications of proteins}

Bottom-up proteomic analysis was carried out in nano-LC-MS/MS (nano-liquid chromatography tandem mass spectrometry) in triplicates.

\section{Pretreatment of sample}

Samples $(100 \mu \mathrm{g})$ were dissolved in $50 \mathrm{mM}$ ammonium bicarbonate, $\mathrm{pH}$ 7.5. After reduction/alkylation (dithiothreitol at a final concentration of $10 \mathrm{mM}, 2 \mathrm{~h}, 37^{\circ} \mathrm{C} /$ iodoacetamide at final concentration of $50 \mathrm{mM}, 30 \mathrm{~min}$ in the dark at room temperature), $2 \mu \mathrm{g}$ of trypsin (modified sequencing-grade trypsin, Roche) in $150 \mathrm{mM}$ ammonium carbonate at $\mathrm{pH} 7.5$, were added and proteins were incubated overnight at $37^{\circ} \mathrm{C}$ while shaking. Then, the reaction was stopped with $10 \mu \mathrm{L}$ of $10 \%$ aqueous formic acid (v/v) and the peptides desalted on C18 stage tips micro desalting devices (ZipTip; Millipore Co.) according to the manufacturer's instructions.

\section{LC-MS/MS}

The system consisted of a RSLC Ultimate 3000 (RSLC nanosystem, Thermo Fisher Scientific) connected to a FT-ICR mass spectrometer (LTQ-FT Ultra, Thermo Fisher Scientific) using a nano-ESI source (TriVersa NanoMate, Advion Biosciences).

Six microlitre samples were injected after appropriate dilution on a capillary reversed-phase precolumn (C18 Acclaim PepMap100, 300- $\mu \mathrm{m}$ i.d., 5-mm length, 5- $\mu \mathrm{m}$ particle size; Thermo Scientific) before separation on a capillary reversed-phase analytical column (C18 Acclaim PepMap100, 75- $\mu \mathrm{m}$ i.d., 50-cm length, 3- $\mu \mathrm{m}$ particle size; Thermo Scientific), at a constant flow rate of $220 \mathrm{~nL} / \mathrm{min}$ at $35{ }^{\circ} \mathrm{C}$, with a gradient $2-40 \%$ buffer $\mathrm{B}$ in buffer A in $180 \mathrm{~min}$ (buffer A: water/acetonitrile/ trifluoroacetic acid 98:2:0.1 (v/v/v), buffer B: water/acetonitrile/trifluoroacetic acid 10:90:0.1). Mass spectrometry was performed using the Top7 data-dependent acquisition method using the software Xcalibur 2.0.7 (Thermo Fisher Scientific): 1 full-scan FT MS at resolution 60,000; range of $470-2000 \mathrm{~m} / z$, followed by seven LTQ MS/MS on the seven most intense peaks, with 90-s dynamic exclusion. 


\section{Protein identification}

Proteome discoverer 2.2 (Thermo Fisher Scientific) was used to process the data and filter the results. All the data were submitted to Mascot search engine 2.6 (Matrix Science) against a concatenated sequence database built from the sequenced genomes of Aspergillus niger strains CBS513.88 and ATCC1015, Triticum aestivum and Brassica napus (all data from NCBI). The sequences from strains CBS513.88 and ATCC1015 were cured to eliminate redundancies. The following parameters were used: trypsin specificity, up to 2 miss cleavages; MS tolerance $10 \mathrm{ppm}$; MS/MS tolerance $0.5 \mathrm{Da}$, carbamidomethyl (Cys) as static modification, and oxidation (Met), deamidation (Asn, Gln), methylation (Asp, Arg, Lys), dimethylation/trimethylation (Arg, Lys) and methylation (Asp) as dynamic modifications. Results were further filtered out using False Discovery Rate (FDR) $0.01 \%$ threshold, minimum 2 peptides per protein and $2 \mathrm{ppm}$ MS error tolerance. Label-free quantification was performed with Minora feature detection after retention-time alignment and feature detection. Intensity-based measurement was used from unique and razor peptides and was assigned to master proteins only.

\section{Purification of enzymes}

The optimized procedure for protein purification is shown in Fig. 3.

\section{Protein fractionation by $\left(\mathrm{NH}_{4}\right)_{2} \mathrm{SO}_{4}$}

Fractionation was obtained by cascaded additions of $40 \%$, $55 \%, 65 \%$ and $100 \%$ of salt (based on saturation point). At each step, precipitation was carried out by stirring on ice for $30 \mathrm{~min}$, and the solution was then centrifuged at $5000 \times g$ for $15 \mathrm{~min}$ at $4{ }^{\circ} \mathrm{C}$. The protein pellets were solubilized in a solution of $0.02 \mathrm{M}$ histidine and $1.0 \mathrm{M}$ ammonium sulfate $\mathrm{pH} 6.0$ for further chromatography steps.

\section{Chromatography}

The system used for the purification of enzymes by chromatography was an Äkta purifier (GE Healthcare). For each method, collected fractions were analyzed for protein and enzymatic activities. The active fractions were pooled, assayed and stored at $-20^{\circ} \mathrm{C}$.

\section{Anion-exchange chromatography (IEXa)}

Anion-exchange chromatography (IEXa) was carried out on a manually mounted column of $50 \mathrm{~mL}$ Sephadex Q FF gel (GE Healthcare). Chromatography was performed at $4{ }^{\circ} \mathrm{C}$, at the flow rate of $10 \mathrm{~mL} / \mathrm{min}$. At the start, the column was in a solution of $0.02 \mathrm{M}$ Histidine $\mathrm{pH}$ 6.0. After equilibration, the samples $(200 \mathrm{~mL})$ were loaded on the column and 6-mL fractions were collected. Proteins were eluted using a solution of $0.02 \mathrm{M}$ Histidine $+1 \mathrm{M}$ chloride sodium $\mathrm{pH} 6.0$ with a concentration gradient from 20 to $35 \%$. Protein detection was monitored at $280 \mathrm{~nm}$.

\section{Hydrophobic-interaction chromatography (HIC)}

HIC was performed on a 16:20 HP Hiprep phenyl HP column (GE Healthcare). Chromatography was performed at $20{ }^{\circ} \mathrm{C}$ with a flow rate of $3 \mathrm{~mL} / \mathrm{min}$. After equilibration with a solution of $0.02 \mathrm{M}$ histidine and $1.0 \mathrm{M}$ ammonium sulfate $\mathrm{pH} 6.0$, the samples $(20 \mathrm{~mL})$ were loaded and $6 \mathrm{~mL}$ fractions were collected. Proteins were eluted using a solution of $0.02 \mathrm{M}$ histidine pH 6.0 with concentration gradient from 0 to $100 \%$.

\section{Size-exclusion chromatography (SEC)}

SEC was carried out with a Hiload Superdex column of 16-mm diameter and 600-mm length from GE Healthcare $(120 \mathrm{~mL}$ of gel). The mobile phase was a solution of $0.1 \mathrm{M}$ ammonium acetate $\mathrm{pH} 5.0$, and the flow rate was $1 \mathrm{~mL} / \mathrm{min}$. Samples of $2 \mathrm{~mL}$ were injected.

\section{Corn ethanol fermentation}

Corn ethanol fermentation was carried out at laboratory scale under conditions reflecting the ones conducted in industrial corn fuel ethanol plants.

\section{Corn mash}

Corn grain was ground using a hammer mill (Electra) with a $0.8-\mathrm{mm}$ grid. Mash was composed of $36 \%$ of corn ground, $10 \%$ of thin stillage and $56 \%$ of water. The slurry was first heated to $60{ }^{\circ} \mathrm{C}$ in a 4-L bioreactor stirred at $250-350 \mathrm{rpm}$. $\mathrm{pH}$ was adjusted to 5.5 with sulfuric acid. Liquefaction of starch was carried out by the addition of an alpha-amylase (Liquozyme SC DS, Novozymes) at $150 \mathrm{~g}$ per ton of corn and heating to $90{ }^{\circ} \mathrm{C}$ during $2 \mathrm{~h}$. At the end of liquefaction, $\mathrm{pH}$ was adjusted to 5.3 with sulfuric acid. The mash was stored at $-20{ }^{\circ} \mathrm{C}$.

\section{Microorganism}

Dry active yeast Saccharomyces cerevisiae Ethanol $\operatorname{Red}^{\circledR}$ (Fermentis) was used for ethanol fermentation. Prior to use yeast was rehydrated in tryptone salt broth $(1 / 10 \mathrm{w} / \mathrm{v})$ at $35^{\circ} \mathrm{C}$ for $30 \mathrm{~min}$.

\section{Ethanol fermentation}

Simultaneous saccharification and fermentation was carried out at $32{ }^{\circ} \mathrm{C}$ during $51 \mathrm{~h}$, in either flasks or bioreactors. The corn mash was inoculated with yeast to guarantee an initial concentration of $1.10^{7}$ cell/ $\mathrm{mL}$. Urea was added at $1 \mathrm{~g} / \mathrm{L}$ as nitrogen source. 
Glucoamylase (Spirizyme Excel XHS, Novozymes) was added at $420 \mathrm{~g}$ per ton of corn. Trials were done in duplicate. Flask model: trials were carried out in 250-mL baffled flasks containing $140 \mathrm{~g}$ of corn mash stirred at $120 \mathrm{rpm}$ in an incubator. The anaerobic conditions were ensured by a rubber stopper and a needle $\left(\varnothing 1.2 \mathrm{~mm}\right.$ ), allowing for the $\mathrm{CO}_{2}$ to evacuate. Mass loss was used to follow ethanol production kinetics. Bioreactor model: trials were carried out in 2.5-L reactors (Biostat $\mathrm{A}+$, Sartorius) containing $2 \mathrm{~kg}$ of corn mash. Stirring was performed at $350 \mathrm{rpm}$ with Rushton blades. Gas meters (MilliGascounter ${ }^{\circledR} 1$, Ritter) allowed to measure $\mathrm{CO}_{2}$ produced during fermentation (flow rate and total volume).

\section{Addition of enzymatic products to corn mash fermentation}

The biocatalyst or the purified fractions of it were added at the beginning of fermentation, along with the other ingredients. The biocatalyst was incorporated at $1 \mathrm{~kg} / \mathrm{T}$ corn. Purified enzymatic fractions were incorporated at appropriate dosage to have equivalent enzymatic activity as added with the biocatalyst at $1 \mathrm{~kg} / \mathrm{T}$ corn.

\section{Analytical methods}

Fermentation kinetics was followed either by mass loss (flask model) or $\mathrm{CO}_{2}$ production measured by gas meter. During or at the end of fermentation, samples were collected for sugars (maltose and glucose), ethanol and glycerol analysis by HPLC. Samples were centrifuged at $3000 \mathrm{rpm}$ for $15 \mathrm{~min}$ at $4{ }^{\circ} \mathrm{C}$. Supernatants were appropriately diluted and filtered ( $25 \mathrm{~mm}$ GDX membrane nylon $0.20 \mu \mathrm{m}$ filter, Whatman) prior to analyses. High-performance liquid chromatography was performed with material from Waters (Isocratic E1515) using a Heater E1500 column. The effect of enzymatic products was calculated by comparison with $\mathrm{CO}_{2}$, ethanol and glycerol produced in control conditions.

\section{Calculation of ethanol yield}

The yield of sugar conversion to ethanol was calculated as

$$
\text { ethanol yield }\left(\frac{\mathrm{g}}{\mathrm{g}}\right)=\frac{\text { ethanol produced }(\mathrm{g})}{\text { initial glucose }(\mathrm{g})}
$$

Initial glucose was determined by complete hydrolysis of corn mash by adding excess dosage of glucoamylase $(2.1 \mathrm{~kg} / \mathrm{T})$ during $16 \mathrm{~h}$ at $55^{\circ} \mathrm{C}$ under agitation $(190 \mathrm{rpm})$, followed by maltose and glucose analysis by HPLC. Total glucose was calculated as

$$
\text { initial glucose }(\mathrm{g})=\text { maltose }(\mathrm{g}) \times 1.1+\text { glucose }(\mathrm{g})
$$

\section{Results and discussion}

\section{Enzymatic composition of the biocatalyst}

The biocatalyst was produced by cultivating, under solid-state fermentation, a selected strain of Aspergillus tubingensis (O27) on a mix of wheat bran and rapeseed meal, as described in "Materials and methods". The strain and blend of substrates were selected based on previous experiments (not shown).

The enzymatic composition of the biocatalyst was characterized. Mass spectrometry analysis of the crude extract allowed to identify 131 proteins, mainly hydrolases. A single protease (aspergillopepsin) accounted for more than half $(58.0 \%)$ of the total proteins. Among the 20 most abundant enzymes, cell-wall-degrading enzymes were highly represented: pectinases (polygalacturonase, 3.9\%; arabinofuranosidase, 2.3\%), cellulases (cellobiohydrolases, $1.4 \%$; endoglucanases, $1.3 \%$; $\beta$-glucosidase, $1.0 \%$ ) and hemicellulases ( $\beta$-xylanases, $4.0 \%$; $\beta$-xylosidase, $1.9 \%$; $\beta$-galactosidases, $1.07 \%$; endo- $1,3-\beta$-glucanase, $0.8 \%)$. Other enzymes such as amylases were also identified. Overall, the 20 most abundant enzymes represented almost $83 \%$ of the enzymatic complex (Fig. 1). Enzymatic assays confirmed that the crude extract contained high levels of protease, pectinase, cellulase and xylanase activity (Table 1).

The enzymatic complexes composition varies greatly with the fungal species, the strain and especially with the growth substrate, as evidenced by Ortiz et al. (2016) or De Vries et al. (2017) for genus Aspergillus. In the SSF technology, substrates have great impact on the quality and quantity of excreted enzymatic complexes. Wheat bran is a fiber-rich material well known to greatly induce enzyme production by SSF, more specifically celluloseand xylans-degrading enzymes (Kang et al. 2004; Bansal et al. 2012; de Vries et al. 2017). Protease production can be induced by protein-rich agro-industrial residues such as cottonseed meal, soybean meal as well as wheat bran (de Castro and Sato 2014; de Castro et al. 2014). This is consistent with obtaining a protease- and cellulases/ hemicellulases-rich enzymatic product by fermenting a strain of Aspergillus on a blend of wheat bran and rapeseed meal.

\section{Effect of the biocatalyst on corn ethanol fermentation}

The crude extract of the biocatalyst was assessed for its effect on ethanol production from corn mash at laboratory scale (conditions based upon industrial data, see "Materials and methods").

The biocatalyst showed a significant positive effect on ethanol production kinetics and yield. Preliminary trials in flasks (data not shown) indicated that optimal effect was obtained with dosages of $0.5-1 \mathrm{~kg} / \mathrm{T}$ corn. When the biocatalyst was added at $1 \mathrm{~kg} / \mathrm{T}$ corn, $\mathrm{CO}_{2}$ release 


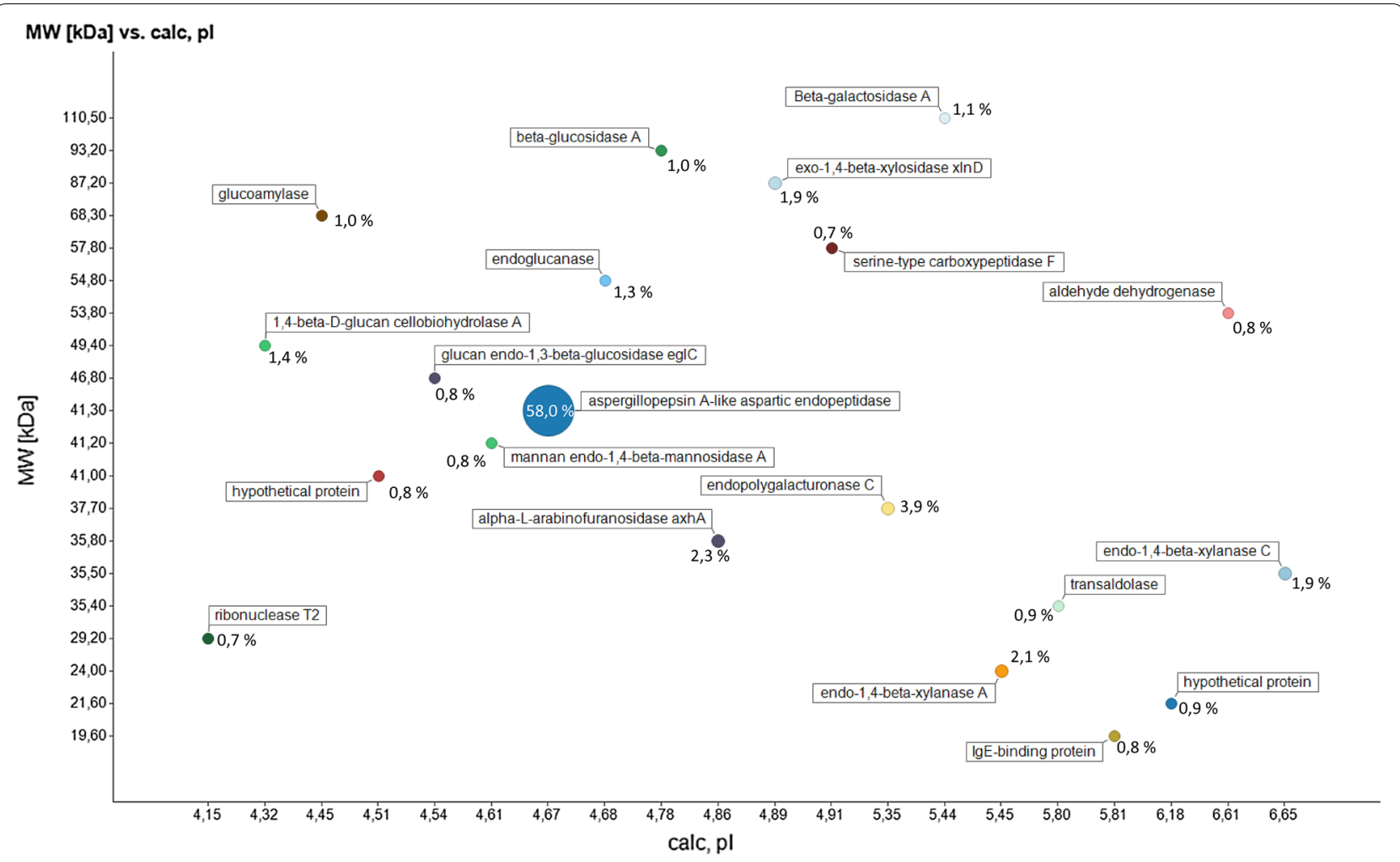

Fig. 1 The twenty major proteins in the crude extract represented per their theoretical molecular weight (MW) and calculated isoelectric pH (calc. pl). Each dot represents an enzyme and the dot size is correlated with the relative abundance

Table 1 Biocatalyst enzymatic profile

\begin{tabular}{ll}
\hline Enzymatic activity & $\begin{array}{l}\text { Unit/g } \\
\text { dry } \\
\text { product }\end{array}$ \\
\hline Protease (PAC) & 115 \\
B-Glucosidase (GLP) & 11.8 \\
Endo-xylanase (AXC) & 208 \\
Polygalacturonase (PG) & 7022 \\
B-Glucanase (AGL) & 235 \\
Cellulase (CMCell) & 195 \\
\hline
\end{tabular}

reached a maximum of $7.8 \mathrm{~L} / \mathrm{h}$ at the end of yeast growth phase, increasing by $28 \%$ the highest value reached in control condition (Fig. 2). After $51 \mathrm{~h}$ of fermentation, total $\mathrm{CO}_{2}$ produced was increased by $7 \%$ and glycerol was reduced by $17 \%$ with the addition of the biocatalyst. Kinetics was accelerated by more than $14 \mathrm{~h}$. Ethanol concentration at $51 \mathrm{hrs}$ reached $134.7 \mathrm{~g} / \mathrm{L}$, which represented an increase by $6.8 \%$ when the biocatalyst was added. Glucose-to-ethanol conversion yield of $45.0 \%$ was, thus, achieved (Table 2). Other trials carried out in flasks with several different industrial-like conditions indicated that final yield increase with the use of the biocatalyst would rather be between 1.5 and 3.5\% (data not shown). The difference in the ethanol increase may be explained by the fact that in this trial the fermentation reaction was not over after $51 \mathrm{~h}$ in the control condition (plateau not reached, Fig. 2).

These results are consistent with those obtained by Hoskins and Lyons (2009), who showed that a solid-state fermented product, obtained with a strain of Aspergillus oryzae cultivated on dried distillers' grains and solubles (DDGS), induced greater corn dextrin hydrolysis. Other studies demonstrated positive impacts of enzymatic products obtained by solid fermentation on fermentation processes. Zimbardi et al. (2013) have shown that an enzymatic product obtained by solid fermentation on wheat bran with a strain of Colletotrichum graminicola, contributed to the release of sugars from sugarcane broth, and thus increased the ethanol potential. Singhania et al. (2015) have shown that a direct use of an enzymatic product (obtained by fermentation in a solid medium of wheat broth with a strain of Penicillium janthinellum) increased the hydrolysis of cellulose Avicel and steam pre-treated wheat straw used for ethanol production, thus contributing to yield improvement. 

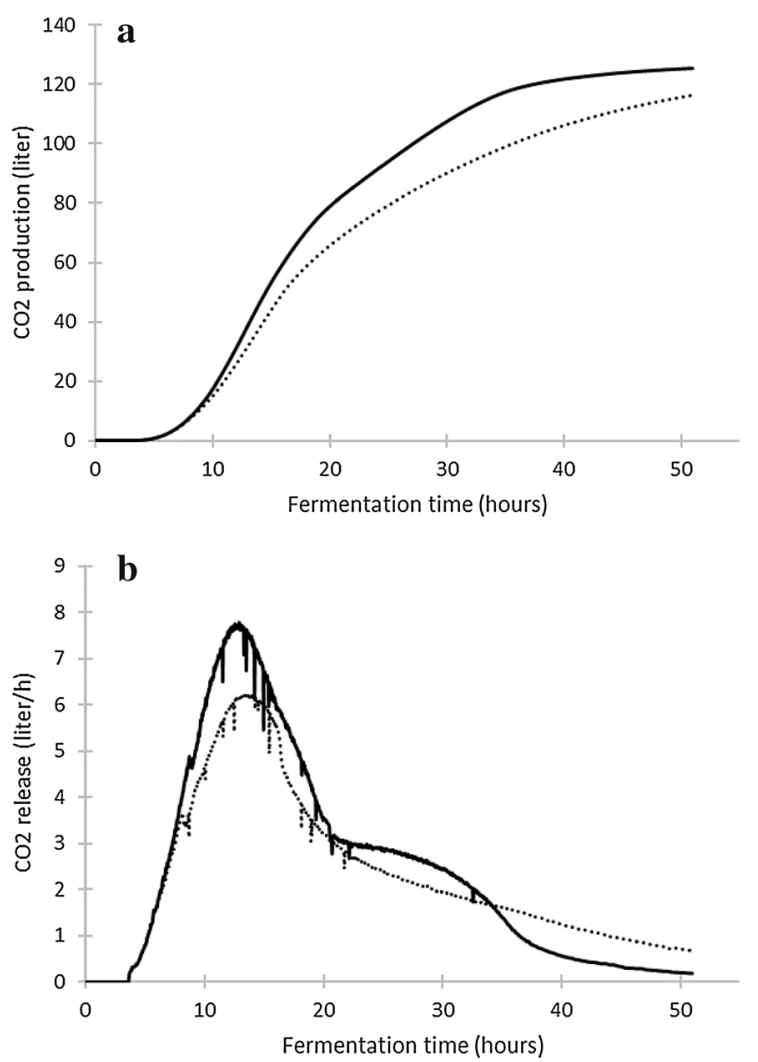

Fig. 2 Increase in $\mathrm{CO}_{2}$ cumulated production $(\mathbf{a})$ and $\mathrm{CO}_{2}$ release rate (b) during corn mash fermentation. Discontinuous line represents control condition; continuous black line corresponds to fermentation with addition of the biocatalyst at $1 \mathrm{~kg} / \mathrm{T}$ corn

Table 2 Impact of the biocatalyst on the production of $\mathrm{CO}_{2}$, ethanol and glycerol after $51 \mathrm{~h}$ of corn mash fermentation in bioreactor model

\begin{tabular}{lcc}
\hline Final sample & Control & Biocatalyst 1 kg/T \\
\hline $\mathrm{CO}_{2}(\mathrm{~L} / \mathrm{L}$ mash $)$ & $58.28 \pm 0.07$ & $62.33 \pm 0.31$ \\
Glycerol (g/L mash) & $12.03 \pm 0.01$ & $10.04 \pm 0.03$ \\
Ethanol (g/L mash) & $126.15 \pm 0.82$ & $134.70 \pm 0.22$ \\
Ethanol conversion yield & $0.420 \pm 0.002$ & $0.450 \pm 0.008$ \\
$\quad$ (g/g initial glucose) & & \\
\hline
\end{tabular}

Data represent average $(n=2) \pm$ standard deviation

Proteolytic activity, which constitutes the main part of the enzymatic cocktail, may explain the effect of the biocatalyst measured on corn ethanol production. Indeed, protease may lead to an increase in FAN (free amino nitrogen) levels in the medium, as shown with corn and sorghum by Perez-Carrillo et al. (2012). The increase in FAN levels may also be consistent with less glycerol produced and higher ethanol yields (Albers et al. 1996). In terms of yeast metabolism, FAN is a direct usable source of amino acids for yeast protein synthesis, which suggests less need for using the tricarboxylic-acid circle. As this metabolic pathway is responsible for NADH production, less use may result in less glycerol production as a way to regenerate NAD + . As a consequence, the glucose catabolism pathway may be preferably oriented to generate energy for the yeast cell, through ethanol production (Rose and Harrison 1989).

\section{Purification of the major proteins of the biocatalyst}

To confirm and specify the part of protease and the other enzymes in the overall effect of the biocatalyst on corn ethanol production, the biocatalyst was fractionated. Seven enzymes among the most abundant were purified following a three-step purification methodology: capture, intermediate purification and polishing (Fig. 3). The fractions generated during enzyme purification were separated by one-dimensional SDS-PAGE Electrophoresis as shown in Fig. 4 and each fraction of purified enzymes was subjected to liquid digestion with trypsin prior to nano-LC-MS/MS analysis (data not shown). The fractions were shown to be practically pure, only one band per lane was observed except for the Fraction A-65\%-2b, where the xylanase $\mathrm{C}$ band and the cellobiohydrolase $\mathrm{A}$ band (lane 8) were found. There was also a slight contamination of fraction A-65\%-1 (lane 1) containing endoglucanase A by endo-1,4-beta-xylanase A. Specific activity was increased by 13 -fold in the protease fraction (aspergillopepsin) and up to 250 -fold in the $\beta$-glucosidase A fraction as shown in Table 3.

Proteomic analysis confirmed that the purified enzymes corresponded to seven of the most abundant enzymes having proteolytic and cell-wall-degrading activity, identified in the crude extract (data not shown), except for the endoglucanase A (an enzyme having $\beta-1,3-$ glucanase activity) which was not identified in the biocatalyst at first. A further analysis of mass spectrometry data showed that it was due to the strict validation criteria of protein identification used in the first place (3 unique peptides), and that two unique peptides of the endoglucanase A were sequenced in the initial extract (data not shown). Together, the enzymes purified from the biocatalyst contributed to almost $70 \%$ of the total proteins identified in the biocatalyst.

Only two enzymes could not be isolated from one another: endo-xylanase $\mathrm{C}$ and cellobiohydrolase A. Although their theoretical pI (isoelectric point) was very different (4.32 and 6.65) and the difference in their molecular weight was greater than between other purified enzymes (Fig. 1), anion-exchange, hydrophobicinteraction and size-exclusion chromatography steps did not allow to separate them. According to the theoretical 


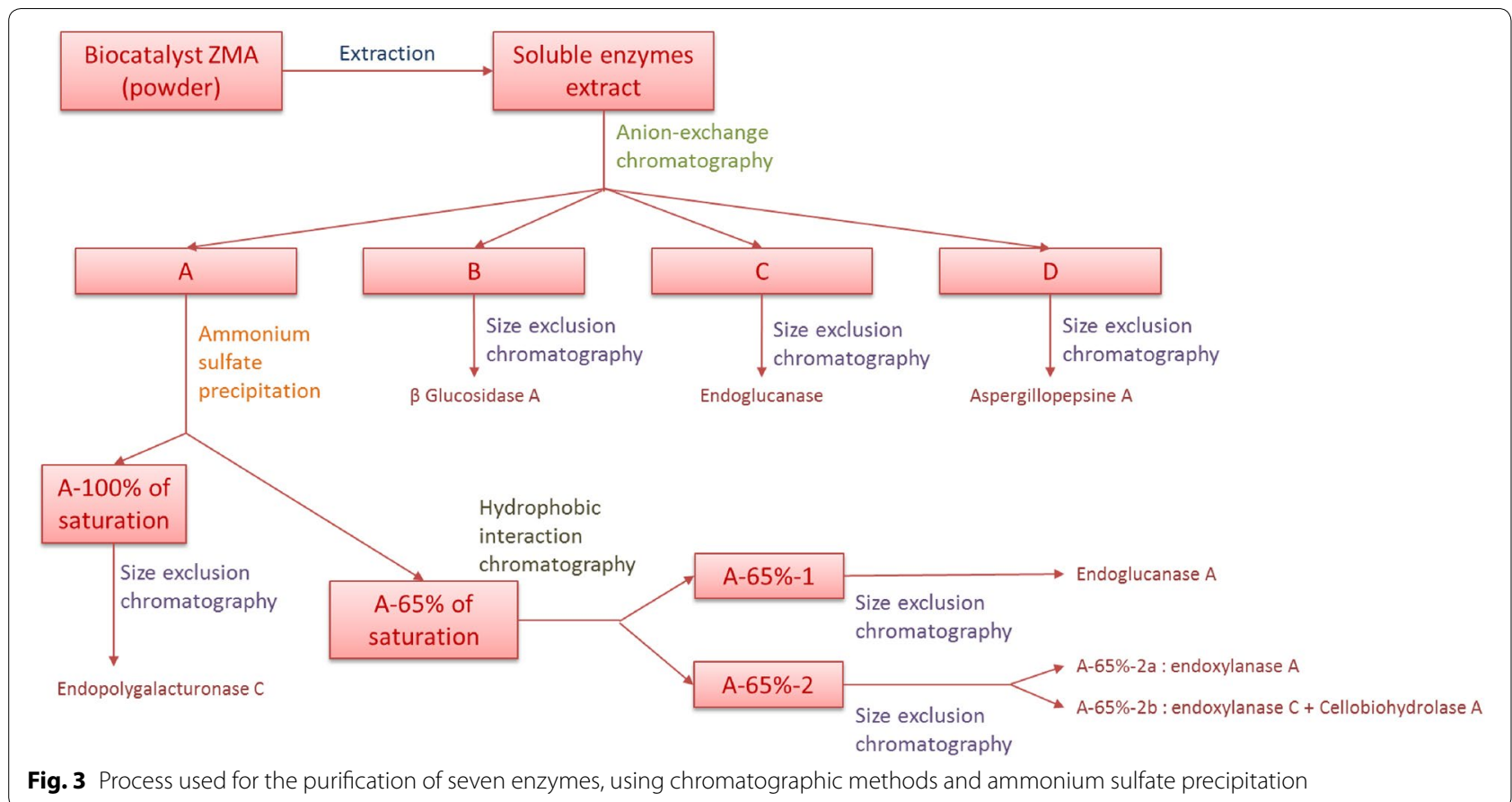

Fig. 3 Process used for the purification of seven enzymes, using chromatographic methods and ammonium sulfate precipitation



pI of endo-xylanase $C$, this enzyme would have had to interact with the anion-exchange medium under experimental conditions. It means the actual pI of endo-xylanase $\mathrm{C}$ would be $<5$. The use of either a more resolving size-exclusion chromatography column, or other chromatographic methods such as cation-exchange chromatography or chromatofocusing, may allow to separate endoxylanase $\mathrm{C}$ from cellobiohydrolase $\mathrm{A}$.

\section{Effect of individual and combined enzymes purified from the biocatalyst on ethanol production}

The fractions of purified protease, cellulases, xylanases and pectinase were assessed in lab-scale fermentation trials to characterize the effect of each enzyme fraction on corn ethanol production. Combinations were also made to identify synergistic effects. To compare their impact, enzymatic fractions were added to corn mash at same enzymatic levels as with the biocatalyst added 
Table 3 Specific activity of enzymatic fractions and purification efficiency by compared to the crude extract

\begin{tabular}{lllcr}
\hline Sample & Enzymatic activity & $\begin{array}{l}\text { Specific activity in purified } \\
\text { fractions (U/mg) }\end{array}$ & $\begin{array}{l}\text { Specific activity in biocatalyst } \\
\text { crude extract (U/mg) }\end{array}$ & $\begin{array}{l}\text { Fold } \\
\text { purification }\end{array}$ \\
\hline Fraction D & Protease & 7.70 & 0.582 & 13 \\
Fraction B & B-Glucosidase & 14.3 & 0.057 & 251 \\
Fraction A-65\%-2a & Endo-xylanase & 42.8 & 0.596 & 72 \\
Fraction A-65\%-2b & Endo-xylanase & 69.2 & 0.596 & 116 \\
Fraction A-100\% & Polygalacturonase & 1882 & 19.7 & 96 \\
Fraction A-65\%-1 & B-Glucanase & 187 & 0.781 & 239 \\
Fraction C & Cellulase & 39.4 & 0.628 & 63 \\
\hline
\end{tabular}

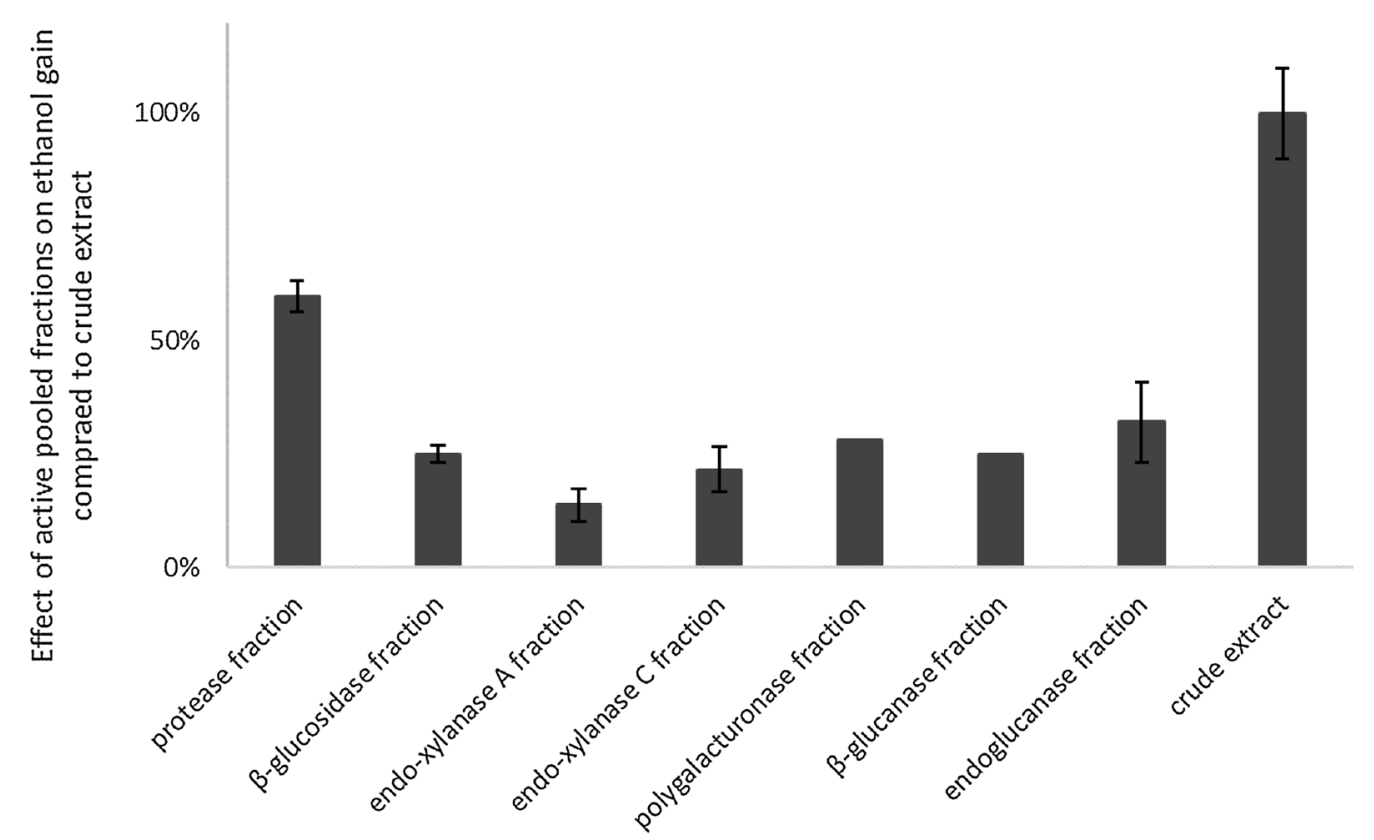

Fig. 5 Effect of each enzymatic purified fraction on ethanol production after $51 \mathrm{~h}$ of corn mash fermentation, as \% of the increase obtained with the addition of the crude extract (100\%) compared with control condition (0\%). Error bars represent standard deviation $(n=2)$. The crude extract was added at equivalent of 1-kg dry product/T corn; the fractions were added at iso-enzymatic activity compared to the crude extract

at $1 \mathrm{~kg} / \mathrm{T}$. Interestingly, all seven fractions had a positive impact on ethanol production (Fig. 5). The protease was found to have the greatest impact among the enzymes and increased ethanol concentration by up to $60 \%$ of the overall effect of the crude extract. Levels of increase in final ethanol with the addition of protease were consistent with those of $2 \%$ obtained by McAloon and Johnston (2014) with the use of a commercial protease. The predominant part of proteolytic activity in the effect of the biocatalyst was, therefore, confirmed, although the crude extract kept a significant advantage over the single protease at same proteolytic activity level. As previously discussed, proteolytic activity induces FAN release which results in change in yeast metabolism and allow for more ethanol production.
Adding purified fractions of cellulases (endoglucanases or $\beta$-glucosidase) and xylanases into corn mash resulted in an increase in ethanol production of $0.3-0.6 \%$ after $51 \mathrm{~h}$ of fermentation, corresponding to $15-30 \%$ of the overall effect of the crude extract (Fig. 5). Such effect may be due to the hydrolysis of corn fibers, liberating reducing sugars to be fermented by the yeast, as shown by Zimbardi et al. (2013) with sugarcane, and by Idris et al. (2017) on sorghum stover. By adding cellulases obtained after solid-state fermentation of wheat bran by a strain of Trichoderma reesei, Yamane et al. (2002) also measured increases in alcohol production from sake mash. They showed that supplementation by a $\beta$-glucosidase had synergistic effect and further increased ethanol production, which our results tend to confirm. 


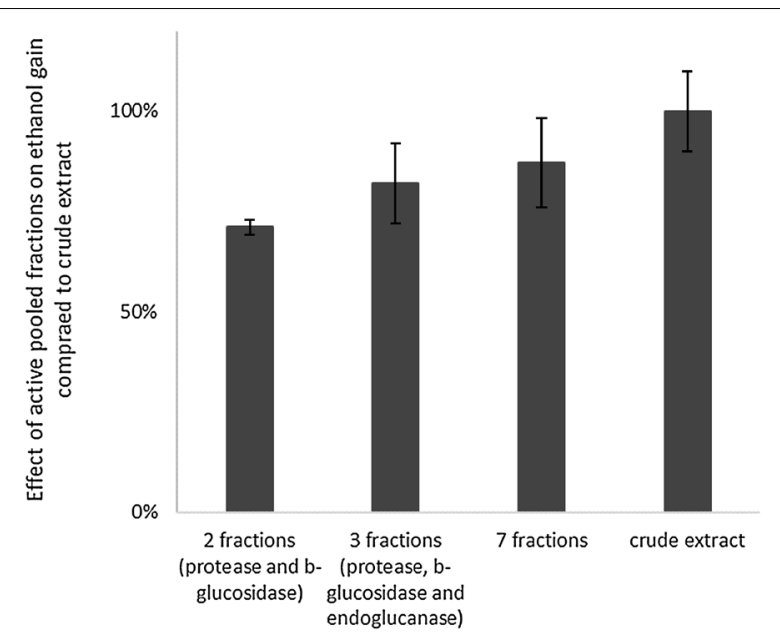

Fig. 6 Effect of pooled fractions on ethanol production after $51 \mathrm{~h}$ of corn mash fermentation, as \% of the increase obtained with the addition of the crude extract (100\%) compared with control condition (0\%). Data represent average of at least 3 replicates, error bars represent standard deviation. The crude extract was dosed at equivalent of 1-kg dry product/ $T$ corn; the fractions were added at iso-enzymatic activity compared to the crude extract
Several pools of purified enzymatic fractions were formed to assess the combined effect of enzymes on ethanol production. The maximal effect was measured with the combination of all seven fractions (Fig. 6), indicating that each of these enzymes play a part in the overall effect of the biocatalyst. This combination allowed to reach $90 \%$ of the effect of the biocatalyst, while the enzymes accounted for approximately $70 \%$ of the total protein content. Our results indicate that the enzymes implicated in protein- and cell-wall degradation indeed have positive impact on ethanol production from corn as stated by literature.

Optimal combinations were found to be of protease together with cellulase (endoglucanase), and further associated with $\beta$-glucosidase. These combinations allowed to reach $70 \%$ and $80 \%$ of the overall effect of the crude extract, respectively. Yet, the additional two cellulolytic enzymes contribute to only $2 \%$ of the proteins in the biocatalyst. This result corroborate the significant positive effect of combined protease and cellulolytic enzymes on the performance of corn ethanol production, as shown by Kłosowski et al. (2010) and Mikulski et al. (2015). Luangthongkam et al. (2015) also reported the benefit provided by associating enzymes, showing greater performances with the combined use of proteases, phytases and cellulases.
Furthermore, the increase in ethanol yield measured with combinations of purified enzymes was found to be lower than the crude extract. This reveals the complexity in the biocatalyst applicative effect. It is likely that other cell-wall-degrading enzymes identified in the biocatalyst may be involved in the overall effect, such as arabinofuranosidase or mannosidase (Fig. 1).

\section{Conclusion}

This study demonstrated that our biocatalyst, obtained by solid-state fermentation, contained more than 130 enzymes. Thanks to the fractionation of the biocatalyst, the particular effect of seven major enzymes on corn ethanol production was elucidated.

Experiments with isolated and combined pure enzymes showed that, together, the protease and two cellulolytic enzymes (an endoglucanase and a $\beta$-glucosidase) were responsible for $80 \%$ of the overall effect of the biocatalyst. The crude extract of biocatalyst still showed higher performances than the combinations of 7 major enzymes, indicating the implication of minor enzymes, such as other cell-wall-degrading enzymes. Further fractionation works would then be necessary to totally explain the effect of the biocatalyst.

\section{Abbreviations \\ AGL: $\beta$-glucanase activity; AXC: endo-xylanase activity; Cell-p: cellobiohy- drolase activity; CMCell: cellulase activity; GLP: $\beta$-glucosidase activity; PAC: protease activity; PDA: potato dextrose agar; PG: polygalacturonase activity; pl: isoelectric point; SSF: solid-state fermentation.}

\section{Authors' contributions}

As project manager AG conducted the research, together with AT built the experimental design and performed scientific monitoring. AT performed and analyzed the corn ethanol trials. YC set up and performed the enzyme purification work. JV performed the nano-LC-MS/MS analyses and together with YC interpreted the data regarding protein identification. $L L$ conducted the solid-state fermentation operations. All authors contributed to the discussion and the writing of the manuscript. All authors read and approved the final manuscript.

\section{Author details}

${ }^{1}$ Centre de Recherche et Innovation Soufflet, Ets J. Soufflet, Quai Sarrail, 10402 Nogent-sur-Seine cedex, France. ${ }^{2}$ PSL University, ESPCI Paris (SMBP CNRS USR 3149), 10 rue Vauquelin, 75231 Paris cedex05, France.

\section{Acknowledgements}

We would like to thank Patrick Zarzov and Sébastien Givry for their advice with the writing, and Antoine Drevelle for his significant part in the initial research approach. We thank Bpifrance for their financial support of the OSIRIS program of Research and Development related to solid-state fermentation technology.

\section{Competing interests}

The authors declare that they have no competing interests.

\section{Availability of data and materials}

The datasets used and/or analyzed during the current study are available from the corresponding author on reasonable request.

\section{Consent for publication}

Not applicable. 
Ethics approval and consent to participate

Not applicable.

\section{Funding}

The research was funded by Bpifrance as part of the Osiris Program led by Soufflet.

\section{Publisher's Note}

Springer Nature remains neutral with regard to jurisdictional claims in published maps and institutional affiliations.

Received: 5 October 2018 Accepted: 30 January 2019

Published online: 07 February 2019

\section{References}

Albers E, Larsson C, Lidén G, Niklasson C, Gustafsson L (1996) Influence of the nitrogen source on Saccharomyces cerevisiae anaerobic growth and product formation. J Appl Environ Microbiol 62(9):3187-3195

Ashokkumar B, Kayalvizhi N, Gunasekaran P (2001) Optimization of media for $\beta$-fructofuranosidase production by Aspergillus niger in submerged and solid state fermentation. Process Biochem 37:331-338

Bansal N, Tewari R, Soni SK, Soni T (2012) Production of cellulases from Aspergillus niger NS-2 in solid state fermentation on agricultural and kitchen waste residues. Waste Manag 32:1341-1346

Bhargav S, Panda BP, Ali M, Javed S (2008) Solid-state fermentation: an overview. Chem Biochem Eng Q 22(1):49-70

Brahmachari G (2017) Biotechnology of microbial enzymes: production, biocatalysis and Industrial applications. Academic Press, Amsterdam. https:// doi.org/10.1016/B978-0-12-803725-6.00021-2

Carboué Q, Tranier M-S, Perraud-Gaime I, Roussos S (2016) Production of microbial enzymes by solid-state fermentation for food applications. Microbial enzyme technology in food applications. CRC Press, New York, pp 437-451

Chutmanop J, Chuichumcherm S, Chisti Y, Srinophakun P (2008) Protease production by Aspergillus oryzae in solid-state fermentation using agroindustrial substrates. J Chem Technol Biotechnol 83:1012-1018

de Castro RJS, Sato HH (2014) Production and biochemical characterization of protease from Aspergillus oryzae: an evaluation of the physical-chemical parameters using agroindustrial wastes as supports. Biocat Agric Biotechnol 3:20-25

de Castro AM, De Andréa TV, Carvalho DF, Teixeira MMP, Dos Reis Castilho L, Freire DMG (2011) Valorization of residual agroindustrial cakes by fungal production of multienzyme complexes and their use in cold hydrolysis of raw starch. Waste Biomass Valoriz 2:291-302

de Castro RJS, Nishide TG, Sato HH (2014) Production and biochemical properties of proteases secreted by Aspergillus niger under solid state fermentation in response to different agroindustrial substrates. Biocat Agric Biotechnol 3(4):236-245

de Vries RP, Riley R, Wiebenga A, Aguilar-Osorio G, Amillis S, Uchima CA, Anderluh G, Asadollahi M, Askin M, Barry K, Battaglia E, Bayram O, Benocci T, Braus-Stromeyer SA, Caldana C, Canovas D, Cerqueira GC, Chen FS, Chen WP, Choi C, Clum A, dos Santos RAC, Damasio ARD, Diallinas G, Emri T, Fekete E, Flipphi M, Freyberg S, Gallo A, Gournas C, Habgood R, Hainaut M, Harispe ML, Henrissat B, Hilden KS, Hossain A, Hope R, Karabika E, Karaffa L, Karanyi Z, Krasevec N, Kuo A, Kusch H, LaButti K, Lagendijk EL, Lapidus A, Levasseur A, Lindquist E, Lipzen A, Logrieco AF, MacCabe A, Makela MR, Malavazi I, Melin P, Meyer V, Mielnichuk N, Miskei M, Molnar AP, Mule G, Ngan CY, Orejas M, Orosz E, Ouedraogo JP, Overkamp KM, Park HS, Perrone G, Piumi F, Punt PJ, Ram AFJ, Ramon A, Rauscher S, Record E, Riano-Pachon DM, Robert V, Rohrig J, Ruller R, Salamov A, Salih NS, Samson RA, Sandor E, Sanguinetti M, Schutze T, Sepcic K, Shelest E, Sherlock G, Sophianopoulou V, Squina F, Sun H, Susca A, Todd RB, Tsang A, Unkles SE, van de Wiele N, van Rossen-Uffink D, Oliveira JVD, Vesth TC, Visser J, Yu JH, Zhou MM, Andersen MR, Archer DB, Baker SE, Benoit I, Brakhage AA, Braus GH, Fischer R, Frisvad JC, Goldman GH, Houbraken J, Oakley B, Pocsi I, Scazzocchio C, Seiboth B, vanKuyk PA, Wortman J, Dyer PS, Grigoriev IV (2017) Comparative genomics reveals high biological diversity and specific adaptations in the industrially and medically important fungal genus Aspergillus. Genome Biol 18:28-45

Diaz-Godinez G, Soriano-Santos J, Augur C, Viniegra-Gonzalez G (2001) Exopectinases produced by Aspergillus niger in solid-state and submerged fermentation: a comparative study. J Ind Microbiol Biotechnol 26(5):271-275

Gao L, Wang F, Gao F, Wang L, Zhao J, Qu Y (2011) Purification and characterization of novel cellobiohydrolase (PdCel6A) from Penicillium decumbens JU-A10 for bioethanol production. Bioresour Technol 102:8339-8342

Gross KC (1982) A rapid and sensitive method for assaying polygalacturonase using 2-cyanoacetamide. Hort Sci 17:933-934

Guillaume A, Carré YA, Drevelle ASD, Thorigné A (2016) Biocatalyst for manufacturing ethanol from corn. WO2017144590

Harris PV, Xu F, Kreel NE, Kang C, Fukuyama S (2014) New enzyme insights drive advances in commercial ethanol production. Curr Opin Chem Biol 19:162-170

Hölker U, Höfer M, Lenz J (2004) Biotechnological advantages of laboratoryscale solid-state fermentation with fungi. Appl Microbiol Biotechnol 64(2):175-186

Hoskins B, Lyons M (2009) Improving bioethanol yield: the use of solid-state fermentation products grown on DDGS. J Inst Brew 115(1):64-70

Idris ASO, Pandey A, Rao SS, Sukumaran RK (2017) Cellulase production through solid-state tray fermentation, and its use for bioethanol from sorghum stover. Bioresour Technol 242:265-271

Kang SW, Park YS, Lee JS, Hong SI, Kim SW (2004) Production of cellulases and hemicellulases by Aspergillus niger KK2 from lignocellulosic biomass. Bioresour Technol 91:153-156

Kłosowski G, Mikulski D, Kotarska K, Czupryński B (2010) Characterisation of fermentation of high-gravity maize mashes with the application of pullulanase, proteolytic enzymes and enzymes degrading non-starch polysaccharides. J Biosci Bioeng 109(5):466-471

Laemmli UK (1970) Cleavage of structural proteins during the assembly of the head of bacteriophage T4. Nature 227:680-685

Luangthongkam P, Fang L, Noomhorm A, Lamsal B (2015) Addition of cellulolytic enzymes and phytase for improving ethanol fermentation performance and oil recovery in corn dry grind process. Ind Crops Prod 77:803-808

McAloon AJ, Johnston DB (2014) Protease increases fermentation rate and ethanol yield in dry-grind ethanol production. Bioresour Technol 154:18-25

Mikulski D, Kłosowski G, Rolbiecka A (2015) Influence of phytase and supportive enzymes applied during high gravity mash preparation on the improvement of technological indicators of the alcoholic fermentation process. Biomass Bioenergy 80:191-202

Mukhtar H, Ikram-Ul-Haq (2009) Production of acid protease by Aspergillus niger using solid state fermentation. Pak J Zool 41(4):253-260

Oda K, Kakizono D, Yamada O, lefuji H, Akita O, Iwashita K (2006) Proteomic analysis of extracellular proteins from Aspergillus oryzae under submerged and solid-state culture conditions. Appl Environ Microbiol 72(5):3448-3457

Ortiz GE, Noseda DG, Ponce Mora MC, Recúpero MN, Blasco M, Albertó E (2016) A comparative study of new Aspergillus strains for proteolytic enzymes production by solid state fermentation. Enzyme Res 2016:1-11

Panda S, Mishra S, Kayitesi E, Ray R (2016) Microbial-processing of fruit and vegetable wastes for production of vital enzymes and organic acids: biotechnology and scopes. Environ Res 146:161-172

Pandey A, Selvakumar P, Soccol CR, Nigam P (1999) Solid state fermentation for the production of industrial enzymes. Curr Sci 77:149-162

Perez-Carrillo E, Serna-Saldivar SO, Chuck-Hernandez C, Cortes-Callejas ML (2012) Addition of protease during starch liquefaction affects free amino nitrogen, fusel alcohols and ethanol production of fermented maize and whole and decorticated sorghum mashes. Biochem Eng J 67:1-9

Rose AH, Harrison JS (1989) The yeasts, vol 3. Metabolism and physiology of yeasts, 2 nd edn. Academic Press, London

Singh SK, Sczakas G, Soccol CR, Pandey A (2008) Production of enzymes by solid-state fermentation. Current developments in solid-state fermentation. Springer, New York, pp 183-204

Singhania RR, Saini R, Adsul M, Saini JK, Mathur A, Tuli D (2015) An integrative process for bio-ethanol production employing SSF produced cellulase without extraction. Biochem Eng J102:45-48 
Subramaniyam R, Vimala R (2012) Solid state and submerged fermentation for the production of bioactive substances: a comparative study. Int I Sci Nat 3(3):480-486

Vidal BC, Rausch KD, Tumbleson ME, Singh V (2009) Protease treatment to improve ethanol fermentation in modified dry grind corn processes. Cereal Chem 86(3):323-328

Yamane Y, Fujita J, Izuwa S, Fukuch IK, Shimizu R, Hiyoshi A, Fukuda H, Mikami S, Kizaki Y, Wakabayashi S (2002) Properties of cellulose-degrading enzymes from Aspergillus oryzae and their contribution to material utilization and alcohol yield in sake mash fermentation. J Biosci Bioeng 93(5):479-484

Zimbardi AL, Sehn C, Meleiro LP, Souza FH, Masui DC, Nozawa MS, Guimarães LH, Jorge JA, Furriel RP (2013) Optimization of $\beta$-glucosidase, $\beta$-xylosidase and xylanase production by Colletotrichum graminicola under solid-state fermentation and application in raw sugarcane trash saccharification. Int J Mol Sci 14:2875-2902

\section{Submit your manuscript to a SpringerOpen ${ }^{\circ}$ journal and benefit from:}

- Convenient online submission

- Rigorous peer review

- Open access: articles freely available online

- High visibility within the field

- Retaining the copyright to your article

Submit your next manuscript at $\boldsymbol{\nabla}$ springeropen.com 